\title{
Differential Responses of Pak Choi and Edible Amaranth to an Elevated Temperature
}

\author{
San-Gwang Hwang ${ }^{1}$, Hsiao-Chien Chao, and Huey-Ling Lin \\ Department of Horticulture, National Chung Hsing University, 145 Xingda \\ Road, 402 Taichung, Taiwan, Republic of China
}

Additional index words. total phenolic compounds, nitrate concentration, pak choi, edible amaranth, climate change

\begin{abstract}
Global surface temperatures are predicted to increase by 1 to $4{ }^{\circ} \mathrm{C}$ by the year 2100. To unravel the risks from rising temperature to Taiwan's summer leafy vegetable production, the phenotypical and physiological responses of two leafy crops, pak choi (Brassica chinensis L. cv. Quanzhou) and edible amaranth (Amaranthus tricolor L. cv. White leaf), were compared under an elevated temperature. A temperature increase from 28 to $32{ }^{\circ} \mathrm{C}$ resulted in lower leaf calcium, magnesium, and manganese concentrations (dry weight basis) in pak choi without significant changes in shoot dry weight, suggesting potential negative effects of the elevated temperature on pak choi leaf nutrient status. However, increased temperature promoted both root and leaf growth in edible amaranth, which may be beneficial to its yield, making edible amaranth a potential summer leafy vegetable crop for Taiwan. Furthermore, a temperature change from 28 to $32{ }^{\circ} \mathrm{C}$ resulted in a higher leaf nitrate concentration in edible amaranth, because of the lower nitrate reductase activity (NRA). Thus, suitable nitrogen fertilization rates and programs under elevated temperature conditions should be reconsidered in the future. To sum up, a future rise in summer temperatures may impose negative impacts on pak choi leaf nutrient status but positive impacts on edible amaranth production.
\end{abstract}

Daily intake of vegetables is known to be beneficial to human health, but the availability of vegetables is at risk because of the current trend of global warming. Vegetable production is greatly influenced by environmental factors, such as light intensity, temperature, and ambient $\mathrm{CO}_{2}$ concentration. Furthermore, past research has revealed that different crop species may respond differently to elevated temperatures. For example, Lara and Andreo (2011) indicated that C4 plants show higher photosynthesis and growth rates under high light intensity and high temperature conditions. Although the effects of elevated temperatures on warmseason $\mathrm{C} 4$ cereals and weeds are widely studied (Crafts-Brandner and Salvucci, 2002; Du et al., 2009; Pompeiano et al., 2013; Wang et al., 2016), the effects of elevated temperatures on $\mathrm{C} 4$ vegetables such as amaranth remain largely unknown. There is an urgent need to study the physiological responses of C4 vegetables under elevated temperature conditions to fill these knowledge gaps.

Summer vegetable production in Taiwan is quite vulnerable to typhoons, pests, and diseases. After a natural disaster that causes a shortage of fresh vegetables, leafy vegetables

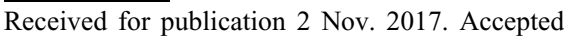
for publication 23 Dec. 2017.

This research was supported by the Ministry of Science and Technology, Taiwan, R.O.C. under Grant no. MOST 104-2313-B-005-045.

${ }^{1}$ Corresponding author. E-mail: sghwang@dragon. nchu.edu.tw. are normally the first to return to markets because of their short growth from seeding to harvest. Because $\mathrm{C} 3$ and $\mathrm{C} 4$ plants have been reported to respond differently to elevated temperatures, we selected one widely grown C3 summer leafy vegetable (pak choi, aka nonheading Chinese cabbage) and one important $\mathrm{C} 4$ summer leafy vegetable (edible amaranth) for this study. A recent study on the effects of sudden increase in temperature on photosynthesis showed that net photosynthesis of Chinese cabbage is decreased when leaf temperature is greater than around $25^{\circ} \mathrm{C}$ (Oh et al., 2015). Furthermore, the effect of long-term elevated temperatures and $\mathrm{CO}_{2}$ on Chinese cabbage was cultivar dependent (Choi et al., 2011). The effects of elevated temperatures on Chinese cabbage root growth and leaf nutrient status were not documented in the above-mentioned studies. However, a recent study reported that some common foods including vegetables could serve as natural sources of antioxidants if they possess a high phenolic content (Kamath et al., 2015). It is of interest to know how elevated temperatures may influence the total phenolic compounds (TPCs) in leafy vegetables. In addition, nitrate content in leafy vegetables is a major concern for vegetable consumers, especially in countries such as Taiwan where consumers prefer eating leafy vegetables. Previous reports indicated that nitrate may turn into nitrite that may then react with some amines or amides to form nitrosamines, which are known to be carcinogenic (Bruning-Fann and Kaneene, 1993; Magkos et al., 2006). Thus, it is important to investigate how elevated temperatures may influence the levels of nutrients, TPCs, and nitrate in leafy vegetables such as pak choi and amaranth.

Leafy vegetables are cultivated extensively in central Taiwan where the climate is subtropical. Results from this study allow us to compare the root growth and the physiological responses of leaves of pak choi (a C3 vegetable) and edible amaranth (a C4 vegetable) under current $\left(28^{\circ} \mathrm{C}\right)$ and elevated $\left(32{ }^{\circ} \mathrm{C}\right)$ temperatures and to further provide relevant information that can lead to the development of strategies to cope with the effect of elevated temperatures on leafy vegetable production in Taiwan and other subtropical regions.

\section{Materials and Methods}

Plant materials and growth conditions. Seeds of pak choi (B. chinensis L. 'Quanzhou') and edible amaranth (A. tricolor L. 'White leaf') were collected from local farmers in Yunlin County, Taiwan. Two growth chambers (Model LBG-500; Lead-Biotech Instruments Co., Ltd., Taichung City, Taiwan) were set at $28 \pm 0.2{ }^{\circ} \mathrm{C}$ and $32 \pm 0.2{ }^{\circ} \mathrm{C}$ to mimic the current and predicted mean summer surface air temperatures of central Taiwan, a subtropical area where leafy vegetables are widely cultivated. The tested vegetables were grown in the growth chambers from seeds. Plants were illuminated with fluorescent light [70 $\mu \mathrm{mol} \cdot \mathrm{m}^{-2} \cdot \mathrm{s}^{-1}$ photosynthetically active radiation $(P A R)]$ under a day/night cycle of $13 \mathrm{~h} / 11$ $\mathrm{h}$. The daytime average relative humidity $(\mathrm{RH})$ inside the growth chambers was determined using an HOBO-U23-001 data logger (Onset Computer Corp., Pocasset, MA).

Measurement of root growth. Pak choi and amaranth seeds were soaked in tap water for $1 \mathrm{~d}$ and then planted at the bottom of a triangular trough made from a rectangular filter paper. The rectangular filter paper was then placed on the surface of a vertical plastic board with its bottom soaking in a plastic container filled with double-distilled water. For each species and each temperature tested, a set of 18 seeds were evenly planted on three vertical plastic boards (six seeds/board). This set was considered one replicate, with a total of three replicates. Root length was recorded daily for a period of 15 and $13 \mathrm{~d}$. The roots of the seedlings were harvested to determine the root fresh weight (FW) and oven-dried at $70{ }^{\circ} \mathrm{C}$ for $5 \mathrm{~d}$ for the dry weight.

Analysis of phenotype and leaf mineral elements, TPCs, nitrate concentrations, and $N R A$. Seeds of pak choi and amaranth were planted in $9-\mathrm{cm} \times 7-\mathrm{cm}$ (diameter $\times$ height) plastic pots containing Potgrond $\mathrm{H}$ substrates (Klasmann-Deilmann Gmbh, Geeste, Germany) at a rate of three seeds per pot. The pots were set into a growth chamber at 28 or $32{ }^{\circ} \mathrm{C}$. Plants were thinned to one plant per pot at $5 \mathrm{~d}$ after sowing (DAS) and fertilized with 1000-fold-diluted Hyponex solution $(\mathrm{N}$ : $\mathrm{P}: \mathrm{K}=20: 20: 20$ ) (Hyponex Japan Co., Ltd., Osaka, Japan) at weekly intervals. For each species tested, a set of 15 pots with a total of 
three sets were planted in each growth chamber. From each set, six pots/plants were randomly selected for phenotypic analysis, and then, leaf samples derived from these plants were subjected to the measurement of leaf mineral elements; furthermore, leaf samples required to determine the concentration of TPCs, the nitrate concentration, and NRA were collected from the rest nine pots/plants. This set was considered one replicate, with a total of three replicates. Pak choi was harvested at 36 DAS, and amaranth was sampled at 37 DAS. Phenotypic analysis including measurement of plant height, stem diameter, leaf length (petiole plus blade length), leaf blade length, leaf width, specific leaf weight (leaf dry weight/leaf area) of the second mature leaf, leaf area, shoot FW, and shoot dry weight on a per-plant basis. The measurement of plant mineral elements was performed according to the methods previously described in Hwang et al. (2015), except that plant samples were used instead of substrate samples. The concentration of TPCs was determined by the method of Keith et al. (1958). Caffeic acid (Sigma-Aldrich, St. Louis, MO) was used to construct the calibration curve. The concentration of TPCs was then calculated and expressed as milligrams of caffeic acid equivalent per $100 \mathrm{~g}$ of FW (mg/100 g FW). The nitrate concentration was measured using an RQflex 10 reflection photometer (Merck, Tokyo, Japan). Nitrate reductase activity was analyzed following the method of Jaworski (1971). A $\mathrm{KNO}_{2}$ solution was used as a standard solution to determine sample NRA ( $\mu \mathrm{mol} / \mathrm{h} / \mathrm{g} \mathrm{FW})$.

Statistical analysis. For all measurements in each species, the significance of the difference between two temperature treatments was determined by calculating sample mean values and SD and analysis of $t$ test using CoStat 6.2 (CoHort Software, Berkeley, CA).

\section{Results and Discussion}

Effect of elevated temperatures on root growth of pak choi and edible amaranth. In pak choi, elevated temperatures increased root length but did not significantly affect root FW, root dry weight, or number of lateral roots. By contrast, edible amaranth roots grew more rapidly and longer as well as had greater root $\mathrm{FW}$, root dry weight, and lateral root number at $32{ }^{\circ} \mathrm{C}$ relative to $28{ }^{\circ} \mathrm{C}$ (Table 1; Fig. 1). These results suggested that a temperature rise benefits young seedling root growth and development in the $\mathrm{C} 4$ plant, amaranth, but not in the $\mathrm{C} 3$ plant, pak choi-a cool-season vegetable. Koscielny and Gulden (2012) suggested that root development provides more relevant information than does shoot development in the early seedling stage, when root growth dominates shoot growth. Moreover, a recent study indicated that early seedling root growth is closely related to yield in wheat (Xie et al., 2017).

Phenotypic analysis of pak choi and edible amaranth under elevated temperature condition. Plants were grown to reach harvest

Table 1. Effect of elevated temperatures on root phenotypes of pak choi and edible amaranth.

\begin{tabular}{lccccc}
\hline Vegetable & Temp $\left({ }^{\circ} \mathrm{C}\right)$ & Fresh wt $(\mathrm{mg})$ & Dry wt $(\mathrm{mg})$ & Length $(\mathrm{cm})$ & NLR/plant \\
\hline Pak choi & 28 & $10.85 \pm 0.38$ & $1.03 \pm 0.09$ & $5.64 \pm 0.294$ & $28.7 \pm 2.11$ \\
& 32 & $10.27 \pm 0.25$ & $0.94 \pm 0.13$ & $7.33 \pm 0.905$ & $29.6 \pm 0.87$ \\
$t$ test & & 0.0915 & 0.4058 & 0.0376 & 0.5246 \\
$P^{\mathrm{y}}$ & & $\mathrm{NS}$ & $\mathrm{NS}$ & $*$ & $\mathrm{NS}$ \\
& & & & & \\
Edible amaranth & 28 & $4.91 \pm 0.7$ & $0.27 \pm 0.12$ & $3.36 \pm 0.112$ & $0.14 \pm 0.096$ \\
& 32 & $9.39 \pm 0.59$ & $0.61 \pm 0.06$ & $8.42 \pm 0.909$ & $3.24 \pm 0.788$ \\
$t$ test & & 0.0011 & 0.0098 & 0.0007 & 0.0025 \\
$P$ & & $* *$ & $* *$ & $* * *$ & $* *$ \\
\hline
\end{tabular}

Values represent the mean \pm SD. The measurement is taken from 15-d-old pak choi seedlings and 13-d-old edible amaranth seedlings.

${ }^{\mathrm{z}}$ Number of lateral roots/plant.

${ }^{\mathrm{y}} P$ from $t$ test: Ns, *,**,*** representing nonsignificant or significant at $P<0.05,0.01$, or 0.001 , respectively.

A

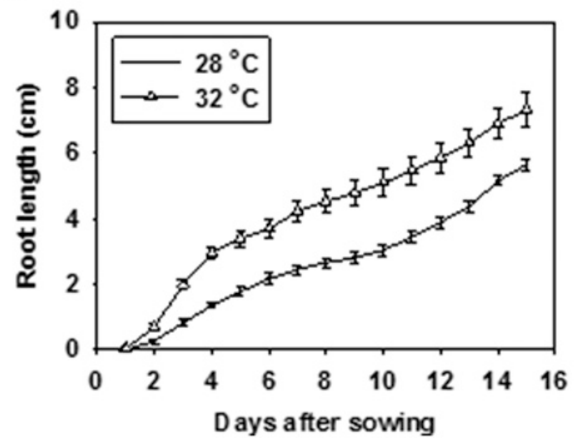

B

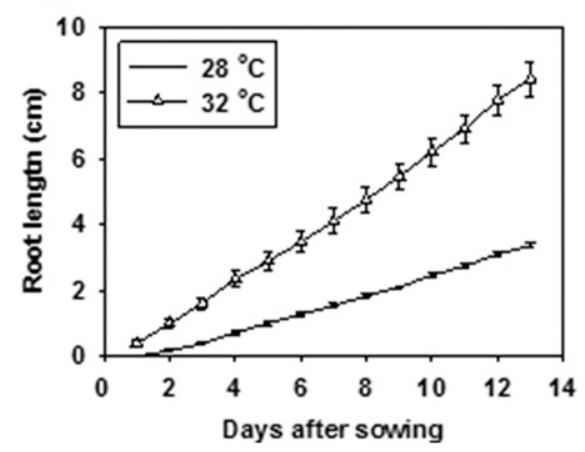

Fig. 1. Effect of elevated temperatures on the root growth of pak choi and edible amaranth. (A) Root length of pak choi grown at 28 and $32{ }^{\circ} \mathrm{C}$ air/ambient temperature. (B) Root length of edible amaranth grown at 28 and $32{ }^{\circ} \mathrm{C}$ air/ambient temperature. The error bars represent the SE of the measurements.

maturity. Pak choi grown at $28{ }^{\circ} \mathrm{C}$ showed a trend toward longer and larger leaves than that grown at $32{ }^{\circ} \mathrm{C}$ by the 36th DAS. However, there was no significant difference in plant height, stem diameter, leaf blade length, leaf width, specific leaf weight, number of leaves per plant, shoot FW per plant, and shoot dry weight per plant between both sets of plants (Tables 2 and 3). Oh et al. (2015) showed that net photosynthesis in Chinese cabbage (Brassica campestris subsp. napus var. pekinensis) is reduced when the temperature exceeds $25^{\circ} \mathrm{C}$, partially because of the associated high respiration rate under high temperatures. Interestingly, this study found no significant differences in most plant phenotypes (e.g., shoot FW and dry weight) between pak choi (B. chinensis L. 'Quanzhou') grown at 28 and $32{ }^{\circ} \mathrm{C}$ (Tables 2 and 3 ), suggesting that net photosynthesis did not decrease at $32{ }^{\circ} \mathrm{C}$ compared with $28{ }^{\circ} \mathrm{C}$. This discrepancy may be due to a lack of difference in day/night temperatures in this study or owing to differential temperature responses between Chinese cabbage and pak choi. However, more research is needed to confirm this assumption.

However, enhanced leaf growth was observed at 37 DAS in edible amaranth cultivated at $32{ }^{\circ} \mathrm{C}$ compared with that grown at $28{ }^{\circ} \mathrm{C}$ (Tables 2 and 3 ). In addition to the enhanced seedling root growth (Table 1; Fig. 1B), amaranth grown at $32{ }^{\circ} \mathrm{C}$ showed greater plant height, stem diameter, leaf length, leaf blade length, leaf width, leaf number, leaf area, shoot FW, and shoot dry weight per plant than plants grown at $28{ }^{\circ} \mathrm{C}$ (Tables 2 and 3 ). These results suggest that an elevated temperature exerts a positive effect on the growth of this $\mathrm{C} 4$ edible crop. It is generally believed that $\mathrm{C} 4$ plants have a higher optimum temperature for photosynthesis; however, inhibition of net photosynthesis can be observed when leaf temperature is greater than $38{ }^{\circ} \mathrm{C}$ (Berry and Björkman, 1980; Crafts-Brandner and Salvucci, 2002). It seems that the upper temperature range used in this study $\left(32^{\circ} \mathrm{C}\right)$ is not exceeding the optimal range for $\mathrm{C} 4$ photosynthesis in edible amaranth. Furthermore, previous research demonstrated that photorespiration losses in C4 plants are limited and that $\mathrm{C} 4$ plants have higher net photosynthetic rates at higher temperatures compared with $\mathrm{C} 3$ plants (Long, 1999). Farquhar et al. (1980) proposed a mathematical leaf model to describe $\mathrm{C} 3$ photosynthesis, and this model has been used to predict that $\mathrm{C} 4$ plants grown under the earth's current $\mathrm{CO}_{2}$ concentration have higher net photosynthetic rates than $\mathrm{C} 3$ plants when temperatures are greater than $22{ }^{\circ} \mathrm{C}$ (Collatz et al., 1998; von Fischer et al., 2008). Taken together, the results from this study suggest that a rise in the summer mean temperature from 28 to $32{ }^{\circ} \mathrm{C}$ caused by climate change has no immediate negative effect on the shoot growth of the C3 crop pak choi, but it may be beneficial to the shoot growth of the $\mathrm{C} 4$ plant edible amaranth. Nonetheless, it is plausible that the combined effect of higher temperatures under ambient light levels would result in greater oxidative 
Table 2. Effect of elevated temperatures on shoot phenotypes of pak choi and edible amaranth.

\begin{tabular}{|c|c|c|c|c|c|c|c|}
\hline$\overline{\text { Vegetable }}$ & Temp $\left({ }^{\circ} \mathrm{C}\right)$ & Plant ht $(\mathrm{cm})$ & Stem diam $(\mathrm{mm})$ & Leaf length $(\mathrm{cm})$ & Leaf blade length $(\mathrm{cm})$ & Leaf width $(\mathrm{cm})$ & Specific leaf wt $\left(\mathrm{mg} \cdot \mathrm{cm}^{-2}\right)$ \\
\hline Pak choi & 28 & $19.9 \pm 0.7$ & $3.2 \pm 0.4$ & $19.2 \pm 0.3$ & $12.1 \pm 0.4$ & $9.6 \pm 0.1$ & $1.09 \pm 0.17$ \\
\hline$t$ test & & 0.94 & 0.13 & 0.02 & 0.06 & 0.11 & 0.75 \\
\hline$P^{z}$ & & NS & NS & * & NS & NS & NS \\
\hline Edible amaranth & 28 & $13.9 \pm 0.2$ & $1.9 \pm 0.1$ & $8.5 \pm 0.4$ & $6.3 \pm 0.3$ & $4.1 \pm 0.05$ & $1.19 \pm 0.03$ \\
\hline & 32 & $23.1 \pm 1.7$ & $3.2 \pm 0.2$ & $11.9 \pm 1.2$ & $8.4 \pm 0.9$ & $5.3 \pm 0.3$ & $1.27 \pm 0.08$ \\
\hline$t$ test & & 0.0007 & 0.0010 & 0.0010 & 0.0193 & 0.0094 & 0.19 \\
\hline
\end{tabular}

Table 3. Effect of elevated temperatures on number of leaves (LN), leaf area, shoot fresh weight, and shoot dry weight on a per-plant basis of pak choi and edible amaranth.

\begin{tabular}{|c|c|c|c|c|c|}
\hline$\overline{\text { Vegetable }}$ & Temp $\left({ }^{\circ} \mathrm{C}\right)$ & $\mathrm{LN} /$ plant $^{\mathrm{z}}$ & Leaf area $\left(\mathrm{cm}^{2}\right) /$ plant & Shoot fresh wt (g)/plant & Shoot dry wt $(\mathrm{g}) /$ plant \\
\hline Pak choi & 28 & $8.2 \pm 0.5$ & $330.8 \pm 13.7$ & $14.1 \pm 1.3$ & $0.56 \pm 0.11$ \\
\hline$t$ test & & 0.19 & 0.01 & 0.09 & 0.17 \\
\hline$P^{\mathrm{y}}$ & & NS & $*$ & NS & NS \\
\hline Edible amaranth & $\begin{array}{l}28 \\
32\end{array}$ & $\begin{array}{r}6.2 \pm 0.2 \\
10.1 \pm 0.3\end{array}$ & $\begin{array}{c}49.9 \pm 3.1 \\
129.8 \pm 12.6\end{array}$ & $\begin{array}{l}1.4 \pm 0.1 \\
4.2 \pm 0.6\end{array}$ & $\begin{array}{l}0.08 \pm 0.01 \\
0.24 \pm 0.04\end{array}$ \\
\hline $\begin{array}{l}t \text { test } \\
P\end{array}$ & & $\begin{array}{c}0.00003 \\
* * *\end{array}$ & $\begin{array}{l}0.0004 \\
* * *\end{array}$ & $\begin{array}{c}0.0011 \\
* *\end{array}$ & $\begin{array}{c}0.0021 \\
* *\end{array}$ \\
\hline
\end{tabular}

Values represent the mean \pm SD. The measurements were taken at $36 \mathrm{~d}$ after sowing (DAS) for pak choi and 37 DAS for edible amaranth.

${ }^{\mathrm{z}}$ Number of leaves per plant.

${ }^{\mathrm{y}} P$ from $t$ test: NS, *,**,*** represented nonsignificant or significant at $P<0.05,0.01$, or 0.001 , respectively.

stress levels, and possibly growth effects in the C3 species, than under the relatively lower light levels used in this study. Thus, if the higher light levels $\times$ higher temperatures do have an additive oxidative stress effect on the $\mathrm{C} 3$ species, a negative effect on the shoot growth of the $\mathrm{C} 3$ crop pak choi may occur when the summer mean temperature rises from 28 to $32{ }^{\circ} \mathrm{C}$. By contrast, it is well established that $\mathrm{C} 4$ photosynthesis demands more energy relative to $\mathrm{C} 3$ photosynthesis; thus, the photosynthetic rate of $\mathrm{C} 4$ edible amaranth was more vulnerable than $\mathrm{C} 3$ pak choi under the low light conditions in this experiment because less adenosine triphosphate (ATP) and nicotinamide adenine dinucleotide phosphate (NADPH) were likely synthesized. It is possible that the positive growth response of $\mathrm{C} 4$ edible amaranth to future elevated temperatures under field conditions would be even more striking than that reported in this study, where a light intensity of $70 \mu \mathrm{mol} \cdot \mathrm{m}^{-2} \cdot \mathrm{s}^{-1}$ PAR was applied. Therefore, future studies should evaluate the effect of temperature rise on leafy vegetable production under ambient light levels. Furthermore, it is worth noting that summer leafy vegetable production in Taiwan normally uses plastic houses and that daily noon temperatures exceed $32{ }^{\circ} \mathrm{C}$. Future research should include effects of extreme high temperatures and of warmer nighttime temperatures on leafy vegetable production.

Another aspect that requires further attention is that the RH inside the growth chambers was not controlled, with a daytime average value of around $46.1 \% \pm 2.1 \%$ and $44.8 \% \pm 1.8 \%$ at 28 and $32{ }^{\circ} \mathrm{C}$, respectively. It seems that each growth chamber reaches its own equilibrium vapor pressure at ambient temperatures of 28 or $32{ }^{\circ} \mathrm{C}$ with minor fluctuations during the day. Compared with the weather data provided by the Central Weather Bureau of Taiwan, the RH inside the growth chambers was lower than the ambient outdoor summer conditions in central Taiwan where the daytime $\mathrm{RH}$ is greater than $50 \%$, and the daily average $\mathrm{RH}$ is around $80 \%$. Tibbitts and Bottenberg (1976) indicated that leaf number, size, dry weight, and water content of butterhead lettuce all increase under $85 \%$ RH than under $50 \%$. Similarly, Ben-Asher et al. (2013) reported that dry matter and water use efficiency in maize were higher under $85 \%$ RH than under $30 \%$. Thus, future research should investigate the interaction between RH and photosynthetic rates in pak choi and edible amaranth. We recognize that we have conducted our experiments in a controlled environment with respect to atmospheric conditions and nutrition. In reality, however, environmental conditions outdoors in the field are considerably different where atmospheric feedback mechanisms are continually causing changes in the environment (e.g., varying temperature, humidity, and wind). Therefore, open-field studies are required to corroborate the results observed in the current study.

Effects of elevated temperatures on pak choi and amaranth leaf nutrient status, nitrate concentration, and NRA. The concentrations of macronutrients and micronutrients in pak choi were compared between plants grown under 28 and $32{ }^{\circ} \mathrm{C}$. Pak choi leaves grown at $32{ }^{\circ} \mathrm{C}$ contained significantly lower concentrations of calcium (reduced by $0.51 \%$ ), magnesium (reduced by $0.19 \%$ ), and manganese (reduced by $17.71 \mathrm{ppm}$ ) than those grown at $28{ }^{\circ} \mathrm{C}$ (Tables 4 and 5). The fact that the concentration of certain mineral elements in pak choi leaves was lower without significant changes in shoot dry weight (Table 3 ) when grown at $32{ }^{\circ} \mathrm{C}$ implies that $32{ }^{\circ} \mathrm{C}$ may induce some stress that affects nutrient uptake or translocation. In addition, previous research indicates that nitrate deficiency promotes increases in both primary and lateral root lengths to facilitate acquisition of meagerly accessible nutrients (Giehl et al., 2014; Linkohr et al., 2002). It is possible that pak choi seedlings developed longer roots at $32{ }^{\circ} \mathrm{C}$ (Table 1; Fig. 1) to compensate for the lower uptake efficiency of certain nutrient elements. However, more research is needed to confirm this hypothesis.

The concentrations of macronutrients and micronutrients in amaranth were compared between plants grown under 28 and $32{ }^{\circ} \mathrm{C}$. The concentrations of magnesium, manganese, and copper in amaranth leaves were slightly increased by $0.08 \%, 10.88 \mathrm{ppm}$, and $5.88 \mathrm{ppm}$, respectively, at $32{ }^{\circ} \mathrm{C}$ compared with those at $28{ }^{\circ} \mathrm{C}$ (Tables 4 and 5), presumably because of the development of longer roots and more lateral roots at $32^{\circ} \mathrm{C}$ (Table 1 ).

When cultivated at $32{ }^{\circ} \mathrm{C}$, the leaves of edible amaranth contained slightly higher concentrations of nitrate than when grown at $28^{\circ} \mathrm{C}$ (Table 6). Interestingly, higher NRA was observed at $28{ }^{\circ} \mathrm{C}$ compared with $32{ }^{\circ} \mathrm{C}$ in edible amaranth. This may explain why the nitrate concentration was lower in edible amaranth leaves when grown at $28{ }^{\circ} \mathrm{C}$ (Table 6). Woodin and Lee (1987) discovered that the induction rate of nitrate reductase increases as the temperature increases at a temperature range between 5 and $20^{\circ} \mathrm{C}$ in Sphagnum. Similar results were also reported in higher plants. For example, Afridi and Hewitt (1965) subjected nitrate-deficient 
Table 4. Effect of elevated temperatures on the concentration of macronutrients in pak choi and edible amaranth (dry weight basis).

\begin{tabular}{lcccccc}
\hline Vegetable & Temp $\left({ }^{\circ} \mathrm{C}\right)$ & $\mathrm{N}(\%)$ & $\mathrm{P}(\%)$ & $\mathrm{Ca}(\%)$ & $\mathrm{K}(\%)$ & $\mathrm{Mg}(\%)$ \\
\hline Pak choi & 28 & $3.47 \pm 0.20$ & $0.49 \pm 0.03$ & $2.44 \pm 0.15$ & $5.77 \pm 0.23$ & $0.74 \pm 0.09$ \\
& 32 & $3.42 \pm 0.13$ & $0.51 \pm 0.02$ & $1.93 \pm 0.04$ & $5.60 \pm 0.26$ & $0.55 \pm 0.01$ \\
$t$ test & & 0.7340 & 0.4315 & 0.0046 & 0.5130 & 0.0211 \\
$P^{z}$ & & $\mathrm{NS}$ & $\mathrm{NS}$ & $* *$ & $\mathrm{NS}$ & $*$ \\
& & & & & & \\
Edible amaranth & 28 & $3.98 \pm 0.07$ & $0.53 \pm 0.02$ & $1.30 \pm 0.11$ & $7.66 \pm 0.25$ & $0.87 \pm 0.03$ \\
& 32 & $3.52 \pm 0.33$ & $0.49 \pm 0.02$ & $1.26 \pm 0.06$ & $7.55 \pm 0.36$ & $0.95 \pm 0.03$ \\
$t$ test & & 0.0741 & 0.0967 & 0.6632 & 0.6715 & 0.0156 \\
$P$ & & NS & NS & NS & NS & $*$
\end{tabular}

Values represent the mean \pm SD. The measurements were taken at $36 \mathrm{~d}$ after sowing (DAS) for pak choi and 37 DAS for edible amaranth.

${ }^{\mathrm{z}} P$ from $t$ test: Ns, ${ }^{*},{ }^{* *}$ represented nonsignificant or significant at $P<0.05$ or 0.01 , respectively.

Table 5. Effect of elevated temperatures on the concentration of micronutrients in pak choi and edible amaranth (dry weight basis).

\begin{tabular}{lccccc}
\hline Vegetable & Temp $\left({ }^{\circ} \mathrm{C}\right)$ & $\mathrm{Fe}(\mathrm{ppm})$ & $\mathrm{Mn}(\mathrm{ppm})$ & $\mathrm{Zn}(\mathrm{ppm})$ & $\mathrm{Cu}(\mathrm{ppm})$ \\
\hline Pak choi & 28 & $81.06 \pm 3.37$ & $50.41 \pm 9.76$ & $63.35 \pm 2.11$ & $10.11 \pm 2.75$ \\
& 32 & $84.93 \pm 3.63$ & $32.70 \pm 3.20$ & $63.56 \pm 1.24$ & $10.55 \pm 1.00$ \\
$t$ test & & 0.2464 & 0.0404 & 0.8874 & 0.8061 \\
$P^{\mathrm{z}}$ & & $\mathrm{NS}$ & $*$ & $\mathrm{NS}$ & $\mathrm{NS}$ \\
& & & & & \\
Edible amaranth & 28 & $75.43 \pm 3.09$ & $46.13 \pm 2.92$ & $55.45 \pm 4.76$ & $5.33 \pm 0.58$ \\
& 32 & $73.16 \pm 2.82$ & $57.01 \pm 2.08$ & $54.73 \pm 1.94$ & $11.21 \pm 1.64$ \\
$t$ test & & 0.3998 & 0.0062 & 0.8201 & 0.0042 \\
$P$ & & $\mathrm{NS}$ & $* *$ & $\mathrm{NS}$ & $* *$ \\
\hline
\end{tabular}

Values represent the mean \pm SD. The measurements were taken at $36 \mathrm{~d}$ after sowing (DAS) for pak choi and 37 DAS for edible amaranth.

${ }^{\mathrm{z}} P$ from $t$ test: Ns, *,** represented nonsignificant or significant at $P<0.05$ or 0.01 , respectively.

Table 6. Effect of elevated temperatures on the concentration of total phenolic compounds (TPCs), nitrate, and NRA in pak choi and edible amaranth leaves.

\begin{tabular}{lcccc}
\hline Vegetable & Temp $\left({ }^{\circ} \mathrm{C}\right)$ & $\mathrm{TPC}(\mathrm{mg} / 100 \mathrm{~g})$ & $\mathrm{NO}_{3}(\mu \mathrm{g} / \mathrm{g} \mathrm{FW})$ & $\mathrm{NRA}(\mu \mathrm{mol} / \mathrm{h} / \mathrm{g} \mathrm{FW})$ \\
\hline Pak choi & 28 & $65.56 \pm 1.28$ & $6,454.04 \pm 363.60$ & $0.52 \pm 0.06$ \\
& 32 & $71.43 \pm 2.75$ & $6,981.77 \pm 79.59$ & $0.40 \pm 0.09$ \\
$t$ test & & 0.0287 & 0.0700 & 0.1204 \\
$P^{\mathrm{z}}$ & & $*$ & $\mathrm{NS}$ & $\mathrm{NS}$ \\
& & & & \\
Edible amaranth & 28 & $61.17 \pm 3.69$ & $3,254.65 \pm 240.45$ & $0.85 \pm 0.02$ \\
& 32 & $58.95 \pm 1.92$ & $4,160.71 \pm 202.17$ & $0.70 \pm 0.05$ \\
$t$ test & & 0.4062 & 0.0075 & 0.0071 \\
$P$ & & $\mathrm{NS}$ & $* *$ & $* *$ \\
\hline
\end{tabular}

FW $=$ fresh weight; NRA $=$ nitrate reductase activity.

Values represent the mean $\pm \mathrm{SD}$. The measurements were taken at $36 \mathrm{~d}$ after sowing (DAS) for pak choi and 37 DAS for edible amaranth.

${ }^{\mathrm{z}} P$ from $t$ test: Ns, $*, * *$ represented nonsignificant or significant at $P<0.05$ or 0.01 , respectively.

cauliflower leaf tissue to various temperatures within the range of 22 to $32{ }^{\circ} \mathrm{C}$ for $3 \mathrm{~h}$ with the treatment of nitrate and found that the induction rate of nitrate reductase decreased as temperature decreased. Intriguingly, when the temperature treatment extended to 6 or $9 \mathrm{~h}$, the induction rate of nitrate reductase in the cauliflower leaf was greater at $22{ }^{\circ} \mathrm{C}$ than at $32{ }^{\circ} \mathrm{C}$, which may be because of the increased inactivation rate of nitrate reductase under long-term high temperature conditions. Consistently, a higher turnover rate of NRA at high temperatures, possibly due to the induction of a certain inactivation enzyme, was suggested by Woodin and Lee (1987). In line with these previous reports, results from this study indicate that long-term exposure to $32{ }^{\circ} \mathrm{C}$ inhibits NRA in $\mathrm{C} 4$ amaranth (Table 6).

Effect of elevated temperatures on the concentration of TPCs in pak choi and amaranth leaves. Pak choi leaves grown at $32{ }^{\circ} \mathrm{C}$ had a higher concentration of TPCs than those grown at $28{ }^{\circ} \mathrm{C}$, whereas no significant difference was noticed in amaranth leaves between both temperatures (Table 6). According to Boscaiu et al. (2010), one of the common plant responses to stress is to generate more plant antioxidants, such as TPCs and total flavonoids. Consistent with the longer seedling root length and the reduced concentration of certain nutrient elements in leaves, the significantly higher amount of TPCs in pak choi leaves at $32{ }^{\circ} \mathrm{C}$ further suggested that pak choi suffered from some stress at this temperature. This higher level of TPCs in pak choi leaves may function to scavenge excessively produced reactive oxygen species (ROS) so that the net photosynthesis remained unaffected, as indicated by the similar shoot dry weight observed in plants grown at 28 and
$32{ }^{\circ} \mathrm{C}$ (Table 3). Nevertheless, additional research is required to determine whether pak choi leaves have different rates of ROS formation, ROS scavenging, and/or net photosynthesis at $32{ }^{\circ} \mathrm{C}$ relative to $28{ }^{\circ} \mathrm{C}$.

\section{Conclusion}

Results from this study suggest that an increase in the mean summer temperatures from 28 to $32{ }^{\circ} \mathrm{C}$ may induce longer seedling root length in the $\mathrm{C} 3$ crop pak choi. However, this temperature increase did not significantly alter root $\mathrm{FW}$, root dry weight, or number of lateral roots. In addition, leaf calcium, magnesium, and manganese concentrations decreased, however, without a significant change in shoot dry weight, representing a possible decline in the uptake or translocation of certain nutrients under elevated temperature conditions. By contrast, an increase in the mean summer temperature had positive growth effects on the $\mathrm{C} 4$ crop edible amaranth. These results are consistent with the general idea that $\mathrm{C} 4$ plants are more resistant to high temperatures. Furthermore, leaf nitrate concentration in edible amaranth was slightly higher at $32^{\circ} \mathrm{C}$ than that at $28^{\circ} \mathrm{C}$, suggesting that nitrate could accumulate to a larger extent in edible amaranth leaves under elevated temperature conditions. Thus, nitrogen application rates and programs should be reevaluated to reduce nitrate accumulation in edible amaranth under elevated temperature conditions. Overall, a future rise in summer temperatures may impose negative impacts on pak choi leaf nutrient status but positive impacts on edible amaranth production. Thus, edible amaranth seems to be a favorable choice as a summer leafy vegetable crop in Taiwan, as well as in other countries, should the surface air temperature continue to climb.

\section{Literature Cited}

Afridi, M.M.R.K. and E.J. Hewitt. 1965. Inducible formation and stability of nitrate reductase in higher plants. II. Effects of environmental factors, antimetabolites, and amino acid on induction. J. Expt. Bot. 16:628-645.

Ben-Asher, J., A. Garcia, I. Flitcroft, and G. Hoogenboom. 2013. Effect of atmospheric water vapor on photosynthesis, transpiration and canopy conductance: A case study in corn. Plant Soil Environ. 59(12):549-555.

Berry, J.A. and O. Björkman. 1980. Photosynthetic response and adaptation to temperature in higher plants. Annu. Rev. Plant Physiol. 31:491-543

Boscaiu, M., M. Sánchez, I. Bautista, P. Donat, A. Lidón, J. Llinares, C. Llul, O. Mayoral, and O. Vicente. 2010. Phenolic compounds as stress markers in plants from gypsum habitats. Bull. Univ. Agr. Sci. Vet. Med. Cluj Napoca Hort. 67(1):44-49.

Bruning-Fann, C.S. and J.B. Kaneene. 1993. The effects of nitrate, nitrite and N-nitroso compounds on human health: A review. Vet. Hum. Toxicol. 35(6):521-538.

Choi, E.Y., T.C. Seo, and S.G. Lee. 2011. Growth and physiological responses of Chinese cabbage and radish to long-term exposure to elevated carbon dioxide and temperature. Hort. Environ. Biotechnol. 52(4):376-386. 
Collatz, G.J., J.A. Berry, and J.S. Clark. 1998. Effects of climate and atmospheric $\mathrm{CO}_{2}$ partial pressure on the global distribution of $\mathrm{C} 4$ grasses: Present, past, and future. Oecologia 114:441-454.

Crafts-Brandner, S.J. and M.E. Salvucci. 2002. Sensitivity of photosynthesis in a C4 plant, maize, to heat stress. Plant Physiol. 129(4):1773-1780.

Du, H., Z. Wang, and B. Huang. 2009. Differential responses of warm-season and cool-season turfgrass species to heat stress associated with antioxidant enzyme activity. J. Amer. Soc. Hort. Sci. 134:417-422.

Farquhar, G.D., S. von Caemmerer, and J.A. Berry. 1980. A biochemical model of photosynthetic $\mathrm{CO}_{2}$ assimilation in leaves of $\mathrm{C}_{3}$ species. Planta 149:78-90.

Giehl, R.F.H., B.D. Gruber, and N. von Wirén. 2014. It's time to make changes: Modulation of root system architecture by nutrient signals. J. Expt. Bot. 65:769-778.

Hwang, S.G., Y.Y. Li, and H.L. Lin. 2015. The use of sawdust mixed with ground branches pruned from wax apple or Indian jujube as substrate for cultivation of king oyster mushroom (Pleurotus eryngii). HortScience 50:1230-1233.

Jaworski, E.G. 1971. Nitrate reductase assay in intact plant tissue. Biochem. Biophys. Res. Commun. 43:1274-1279.
Kamath, S.D., D. Arunkumar, N.G. Avinash, and S. Samshuddin. 2015. Determination of total phenolic content and total antioxidant activity in locally consumed food stuffs in Moodbidri, Karnataka, India. Adv. Appl. Sci. Res. 6(6):99102.

Keith, R.W., D.L. Tourneau, and D. Mahlum. 1958. Quantitative paper-chromatographic determination of phenols. J. Chrom. A 1:534-536.

Koscielny, C.B. and R.H. Gulden. 2012. Seedling root length in Brassica napus L. is indicative of seed yield. Can. J. Plant Sci. 92:1229-1237.

Lara, M.V. and C.S. Andreo. 2011. C4 Plants adaptation to high levels of $\mathrm{CO}_{2}$ and to drought environments. In: A. Shanker (ed.). Abiotic stress in plants - Mechanisms and adaptations. InTech, Rijeka, Croatia.

Linkohr, B.I., L.C. Williamson, A.H. Fitter, and H.M.O. Leyser. 2002. Nitrate and phosphate availability and distribution have different effects on root system architecture of Arabidopsis. Plant J. 29(6):751-760.

Long, S.P. 1999. Environmental responses, p. 215 249. In: R.F. Sage and R.K. Monson (eds.). C4 plant biology. Academic Press, San Diego, CA.

Magkos, F., F. Arvaniti, and A. Zampelas. 2006. Organic food: Buying more safety or just peace of mind? A critical review of the literature. Crit. Rev. Food Sci. Nutr. 46:23-56.
Oh, S., K.H. Moon, E.Y. Song, I.C. Son, and S.C. Koh. 2015. Photosynthesis of Chinese cabbage and radish in response to rising leaf temperature during spring. Hort. Environ. Biotechnol. 56(2):159-166.

Pompeiano, A., M. Volterrani, and L. Guglielminetti. 2013. Physiological responses of $\mathrm{C} 4$ grasses to prolonged heat stress. Adv. Hort. Sci. 27(3):127132.

Tibbitts, T.W. and G. Bottenberg. 1976. Growth of lettuce under controlled humidity levels. J. Amer. Soc. Hort. Sci. 101:70-73.

von Fischer, J.C., L.L. Tieszen, and D.S. Schimel. 2008. Climate controls on C3 vs. C4 productivity in North American grasslands from carbon isotope composition of soil organic matter. Glob. Change Biol. 14:1141-1155.

Xie, Q., K.M.C. Fernando, S. Mayes, and D.L. Sparkes. 2017. Identifying seedling root architectural traits associated with yield and yield components in wheat. Ann. Bot. 119:1115-1129.

Wang, D., S.A. Heckathorn, K. Mainali, and R. Tripathee. 2016. Timing effects of heat-stress on plant ecophysiological characteristics and growth. Front. Plant Sci. 7:1629.

Woodin, S.J. and J.A. Lee. 1987. The effects of nitrate, ammonium and temperature on nitrate reductase activity in Sphagnum species. New Phytol. 105:103-115. 